\title{
Socio-economic and technical characteristics of pig (Sus scrofa domesticus) production system in the humid forest with monomodal rainfall agro- ecological zone of Cameroon
}

\author{
Joseline Sob MOTSA'A ${ }^{1}$, Henry Fualefac DEFANG ${ }^{1,2}$ \\ and Christian Tiambo KEAMBOU ${ }^{3,4^{*}}$ \\ ${ }^{1}$ Department of Animal Production, Faculty of Agronomy and Agricultural Sciences, \\ University of Dschang, Cameroon. \\ ${ }^{2}$ Department of Agriculture, Higher Teacher Technical Training School, University of Buea, Cameroon. \\ ${ }^{3}$ Department of Animal Science, Faculty of Agriculture and Veterinary Medicine, \\ University of Buea, Cameroon. \\ ${ }^{4}$ Biosciences Eastern and Central Africa - International Livestock Research Institute, Nairobi, Kenya. \\ *Corresponding author; E-mail: keambou.tiambo@ubuea.cm /c.tiambo@cgiar.org
}

\begin{abstract}
Pig production has become a great source of income and employment in Sub-Saharan countries and Cameroon in particular. However, many pig farmers face difficulties as the production system has not been improved everywhere. Hence, the present study was conducted in other to assess the socio-economic and technical characteristics of pig production system in the humid forest with monomodal rainfall agro-ecological zone of Cameroon. For this purpose, a total of 45 smallholder pig farmers were selected using a snow ball test from the study zone and investigated. A structural questionnaire was used to interview the pig farmers. Data generated included: socio-economic characteristics of the respondents, housing, breeding, feeding, health care, management practices and challenges in pig production. The data collected were analyzed by descriptive statistics. The study revealed that most of the respondents $(62.2 \%)$ were male and $35.6 \%$ were between $40-69$ years old. $82 \%$ of the pig farmers were married and all $(100 \%)$ were Christians. With regards to education, only $4.4 \%$ of the farmers had no formal education while $55 \%$ had an experience of 10 years in pig farming. Majority of the farmers (44.4\%) jointly reared cross (exotic x local), local and exotic pigs. 57.8\% of farmers feed their pigs with compounded feed associated with kitchen and farm residues twice daily, morning and evening in feeding through mostly made of plastic materials $(37.8 \%) .84 .44 \%$ of farmers housed their pigs to avoid destruction and diseases (64.44\%). Piggeries were mostly made of wood $(60.0 \%)$ and had concrete floors $(57.8 \%)$. However, $22.2 \%$ of farmers practiced free range production system. The farmers mostly practiced free will $(55.6 \%)$ and group mating and delivery takes place in the herd (62.2\%). $77.8 \%$ of the farmers faced health problems and $91.1 \%$ considered pig farming to be profitable. The main challenges faced by farmers were disease outbreak and expensive feed cost (22.2\%). Although pig production is profitable, there is no ready market. Nevertheless, pig production has a positive impact in the lives of rural dwellers.
\end{abstract}

(C) 2018 International Formulae Group. All rights reserved.

Keywords: Socio-economic, pig farmers, Production system, Cameroon.

\section{INTRODUCTION}

Cameroon is estimated to have 1.7 million pigs (Bouba, 2010). Most of this herd is kept by smallholder rural farmers for who it plays a crucial role as it does in numerous tropical countries (Bienvenu et al., 2014). In 
terms of pig production, Cameroon ranks first in the Central African sub region (CEMAC) and second after Nigeria (4.7 million pigs) in West Africa (Defang et al., 2014). This is an important asset and survival strategy for rural and peri-urban poor famers. Keeping pig may offer an opportunity to improve the quality of life through increased cash income from sales and through improved nutrition. Keeping pigs requires low inputs of labour and feed and pig-keeping can easily be combined with domestic work, providing a potential source of empowerment for women. Pigs have been defined as one of the most prolific and fast growing livestock species that can convert food leftovers to valuable products (Vicente et al., 2011). The annual growth rate for pig is estimated to be 16.49 (ILRI, 2000) and its meat is most preferred to that of other red meat animals, such as cattle, sheep and goats. Pig production is one of the best options as source of cheap, high quality dietary protein for the rising African population.

About $80 \%$ of the pigs reared in Cameroon are crossbreds (indigenous $x$ exotic) kept under small scale production systems. Efforts have been directed towards improving their productivity through adequate nutrition, improved health and management and genetic improvement. The improvements in quantity and quality of the pig herd will not only contribute in meeting the nutritional requirements of Cameroonians but will also reduce the huge bills on foreign exchange in the purchase of animal products (Defang et al., 2014). This will also improve the livestock sector of the country as it will be a source of employment to the rural population and income generation. However, Bringing in external development options is unsustainable as they fail to appreciate the complexity of livestock production systems that farmers face. Prior to decision on any planned use for pigs, assessment of socioeconomic characteristics, farm profile and management practices of pig production are required in order to make more efficient and sustainable pig rearing activity (Bienvenu et al., 2014).
Therefore, in view of the above mentioned facts, the present study was planned to describe the socio-economic characteristics of pig producers in the study zone and examine typology of production, that is the management practices and outline some of the main constrains in the humid forest with monomodal rainfall agro-ecological zone of Cameroon.

\section{MATERIALS AND METHODS Study site}

The study was carried out in two divisions and six sub-divisions (Tiko, Buea, Mamfe, Muyuka, Upper-Bayang and Eyumojock) within the following geographical coordinates: $44^{\circ} 10^{\prime} 00^{\prime \prime}$ $5^{\circ} 50^{\prime} 00^{\prime \prime} \mathrm{LN}$ and $9^{\circ} 10^{\prime} 00^{\prime \prime}-9^{\circ} 30^{\prime} 00^{\prime \prime} \mathrm{LE}$. The map of the study zone in presented in Figure 1.

\section{Farmers' household survey}

The targeted population of this study entailed men and women carrying on in pig farming in the study zone. Finally, a total of 45 households' were selected and surveyed using a snow ball test. The sections of the questionnaire included; social characteristics, zoo-technical parameters, management practices and economic evaluation on pig production. Primary data used in this study were collected through face to face interviews, field observations, measurements and responds through structural questionnaires. Interviews were carried out orally at the study site. The questionnaires were administered. Data collected were analyzed using descriptive statistics to calculate mean values and percentages by of statistical package for social sciences.

\section{Ethics statement}

All participating households were informed about the purpose of the study and that their participation was voluntary and anonymous. Verbal consent was obtained from each household and documented in the questionnaire. 


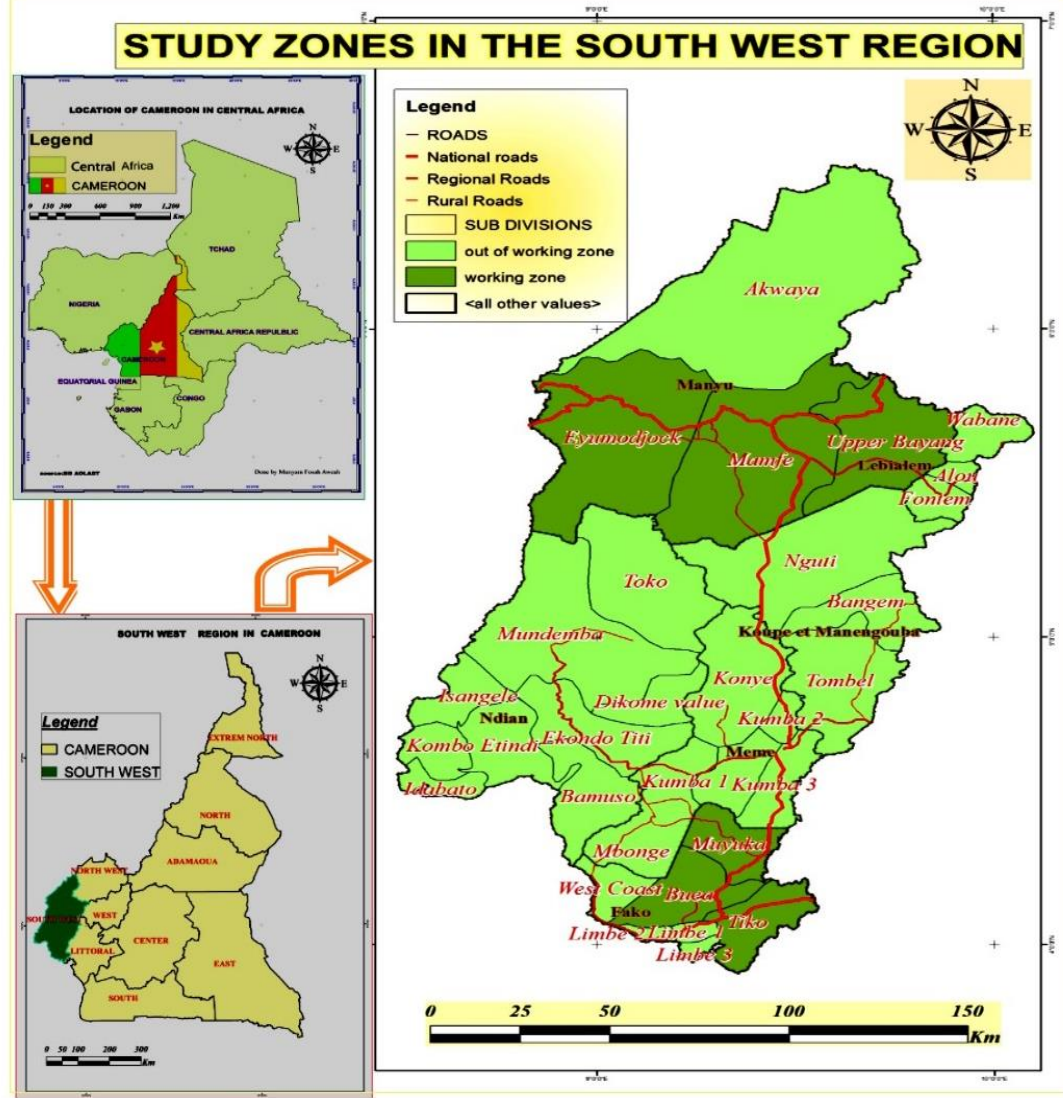

Figure 1: Map of the South West Region in the in the humid forest with monomodal rainfall agroecological zone of Cameroon. Source: National Institute for Cartography.

\section{RESULTS}

\section{Socio-economical characteristics of pig farmers}

Table 1 summarizes the frequency distribution of farmers according to their category and age group. The majority of stallholder pig farmers (88.9\%) in humid forest with monomodal rainfall agroecological zone of Cameroon take care themselves of their herd, though $11.1 \%$ of them request the services of caretakers. Most of those farmers are male $(62.2 \%)$ and are aged between $40-49$ years $(35.6 \%)$. However, young people of less than 30 years are also interested by this activity. Most of the pig breeders have farming as main occupation $(44.4 \%)$, they are married $(82.2 \%)$ and only a very small proportion $(4.4 \%)$ has no formal education. All the pig rearers are Christians
(100\%), the majority $(55.56 \%)$ have been keeping pigs for 1-10 years and have obtain their starter stock from the neighborhoods $(44.44 \%) .40 \%$ of them jointly keep local, exotic and their crossbreeds.

\section{Technical characteristics \\ Housing of animals}

Table 2 shows the characteristics of pig housing in the humid forest with monomodal rainfall agro-ecological zone of Cameroon. $84.44 \%$ of farmers house their pigs to avoid destruction and diseases $(64.44 \%)$. Most of the piggery and wooden $(60.0 \%)$ made with concrete floor (57.8\%). However, a considerable percentage of animals $(35.6 \%)$ are reared on bare floor. The number of farmers practicing free range production system is still relatively high (22.2\%), enough 
to favour spread of diseases. Figure 2 illustrates few of the housing systems found in the humid forest with monomodal rainfall agro-ecological zone of Cameroon.

\section{Animals feeding, reproduction and health protection system}

Table 3 presents the characteristics of pigs feeding. This table reveals that most of the farmers give their animals compounded feed $(57.8 \%)$ twice daily $(57.8 \%)$ in feeding troughs $(84.4 \%)$ mostly made of plastic materials $(37.8 \%)$ and concrete $(28.9 \%)$. For reproduction, farmers practice mostly free will $(55.6 \%)$ and group $(33.3 \%)$ mating systems and delivery mostly take place inside the herd $(62.20 \%) .77 .8 \%$ of farmers declared facing health problems, mostly due to lack of prophylactic measures, non-availability of veterinary products and insufficient technical assistance. Farmers practice different types of health prevention methods, of which the vaccination is predominant $(44.44 \%)$, followed by proper treatment and good hygiene, while $15.56 \%$ of farmers declared taking no preventive methods. This category was mostly made of local pig farmers, who in some remote areas said to have never experienced African swine fever.

\section{Marketing, profitability and challenges faced by farmers}

Table 4 summarizes the distribution of farmers with respect to the marketing and profitability of pig production, as well as the problems they encounter. Although pig production is recognized profitable $(91.11 \%)$, there is no ready market according to $77.78 \%$ of farmers whose main challenges are disease outbreak $(33.33 \%)$ and expensive feed cost $(22.22 \%)$.

Table 1: Sociological characteristics of pig farmers in the humid forest with monomodal rainfall agro-ecological zone of Cameroon.

\begin{tabular}{|c|c|c|c|c|c|}
\hline Variables & Number & Percentage & Variables & Number & Percentage \\
\hline Charge & & & Marital status & & \\
\hline Owner & 40 & 88.9 & Single & 8 & 17.8 \\
\hline Caretaker & 5 & 11.1 & Married & 37 & 82.2 \\
\hline Total & 45 & 100.0 & Total & 45 & 100.0 \\
\hline Age group & & & Religion & & \\
\hline $20-29$ & 10 & 22.2 & Christian & 45 & 100 \\
\hline $30-39$ & 7 & 15.6 & Total & 45 & 100 \\
\hline $40-49$ & 16 & 35.6 & Origin of starter stock & & \\
\hline $50+$ & 12 & 26.7 & Neighbour & 20 & 44.44 \\
\hline Total & 45 & 100.0 & Gov. breeding station & 6 & 13.33 \\
\hline Sex & & & Inheritance & 13 & 28.89 \\
\hline Male & 28 & 62.2 & Peri-urban area & 6 & 13.33 \\
\hline Female & 17 & 37.8 & & & \\
\hline Total & 45 & 100.0 & Total & 45 & 100.0 \\
\hline Main occupation & & & Breed preference / Owne & & \\
\hline Farmer & 20 & 44.4 & Local & 9 & 20 \\
\hline civil servant & 8 & 17.8 & Exotic & 11 & 24.44 \\
\hline Trader & 14 & 31.1 & Local+exotic+crossbreeds & 18 & 40 \\
\hline
\end{tabular}




\begin{tabular}{lcc|lcc} 
Student & 3 & 6.7 & Local+exotic & 7 & 15.56 \\
\hline Total & 45 & 100.0 & Total & 45 & 100.0 \\
\hline Level of education & 2 & 4.4 & $\begin{array}{l}\text { Years of experience } \\
1-10\end{array}$ & $\mathbf{2 5}$ & 55.56 \\
No formal education & & & & & \\
Basic education & 15 & 33.3 & $11-20$ & 4 & 31.11 \\
Secondary education & 17 & 37.8 & $21-30$ & 4.89 \\
High School & 5 & 11.1 & $31-40$ & 2 & 4.44 \\
University level & 6 & 13.3 & & & \\
\hline Total & 45 & 100 & Total & 45 & 100.0 \\
\hline
\end{tabular}

Table 2: Characteristics of pig housing in the humid forest with monomodal rainfall agro-ecological zone of Cameroon.

\begin{tabular}{|c|c|c|c|c|c|}
\hline Variables & Number & Percentage & Variables & Number & Percentage \\
\hline Housing (yes or no) & & & Gate of the house & & \\
\hline Yes & 38 & 84.44 & Metal & 17 & 37.8 \\
\hline No & 7 & 15.56 & Wood & 28 & 62.2 \\
\hline Total & 45 & 100 & Total & 45 & 100.0 \\
\hline Reasons for housing & & & Floor of the piggery & & \\
\hline Avoid destruction and disease & 29 & 64.44 & Bare floor & 16 & 35.6 \\
\hline Avoid theft & 7 & 15.56 & Concrete & 26 & 57.8 \\
\hline Proper healthcare and feeding & 4 & 8.89 & Gravel & 1 & 2.22 \\
\hline Increase production & 5 & 11.11 & Suspended planks & 2 & 4.44 \\
\hline Total & 45 & 100 & Total & 45 & 100.0 \\
\hline Wall of the piggery & & & Production systems & & \\
\hline Mud bricks & 2 & 4.4 & Free range & 10 & 22.2 \\
\hline Cement Blocks & 16 & 35.6 & Semi-intensive & 6 & 13.3 \\
\hline Wooden made & 27 & 60.0 & Intensive & 29 & 64.4 \\
\hline Total & 45 & 100.0 & Total & 45 & 100.0 \\
\hline
\end{tabular}



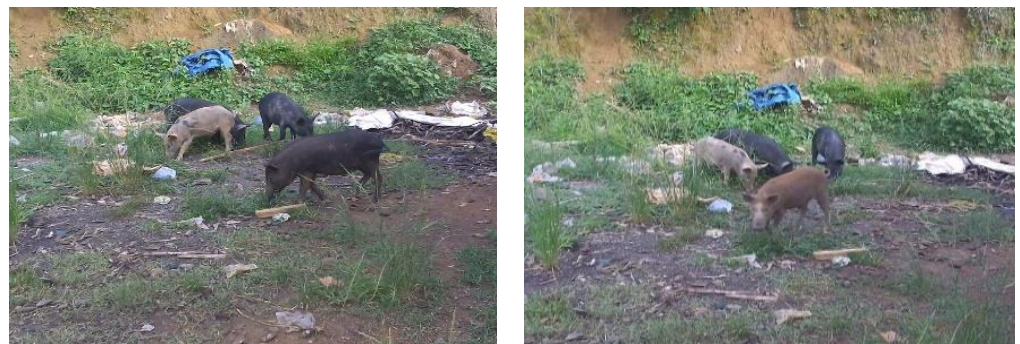

Free ranging pigs
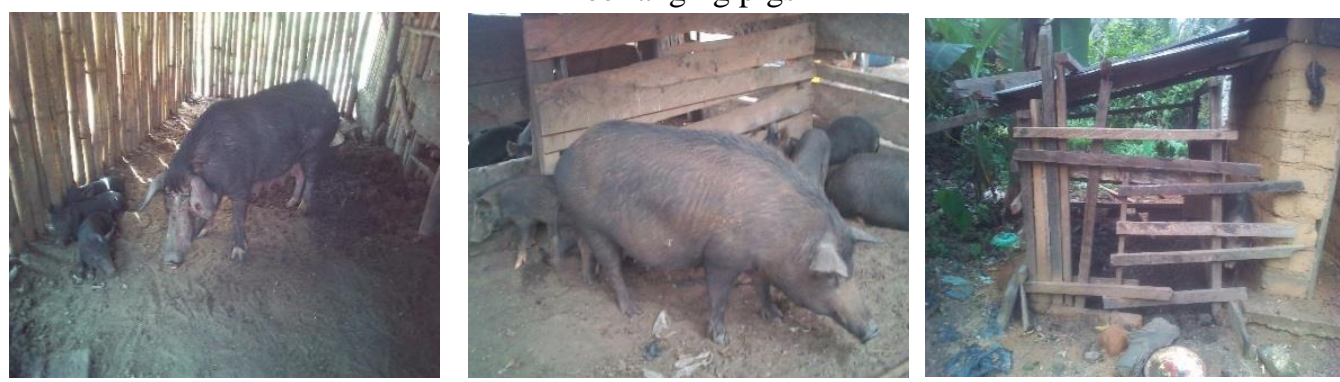

Piggeries with temporal material with bare floor
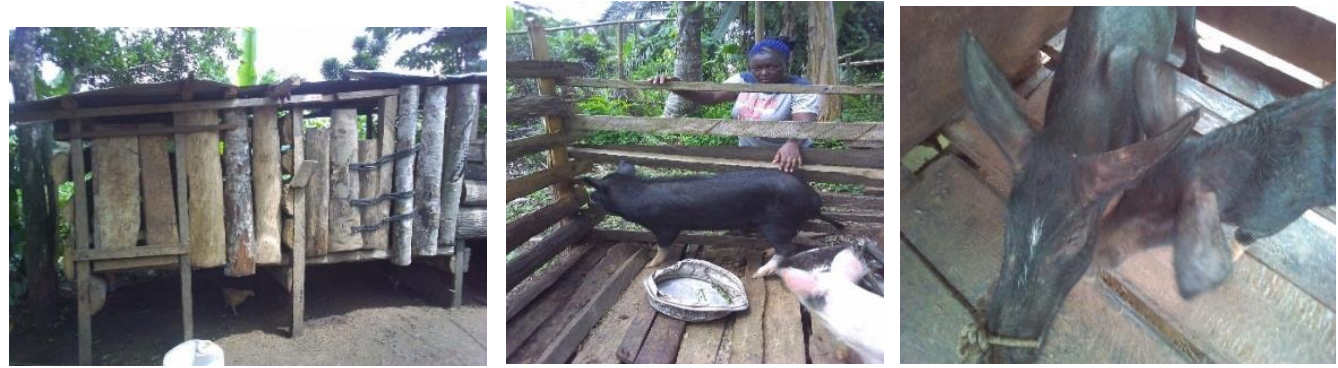

Wooden made suspended piggeries
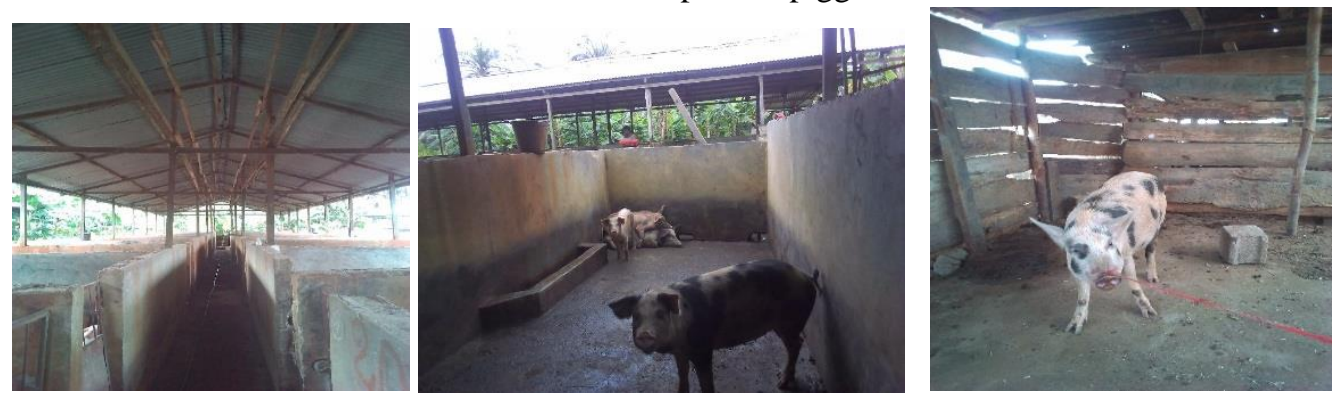

Improved aerated and cemented floor piggeries
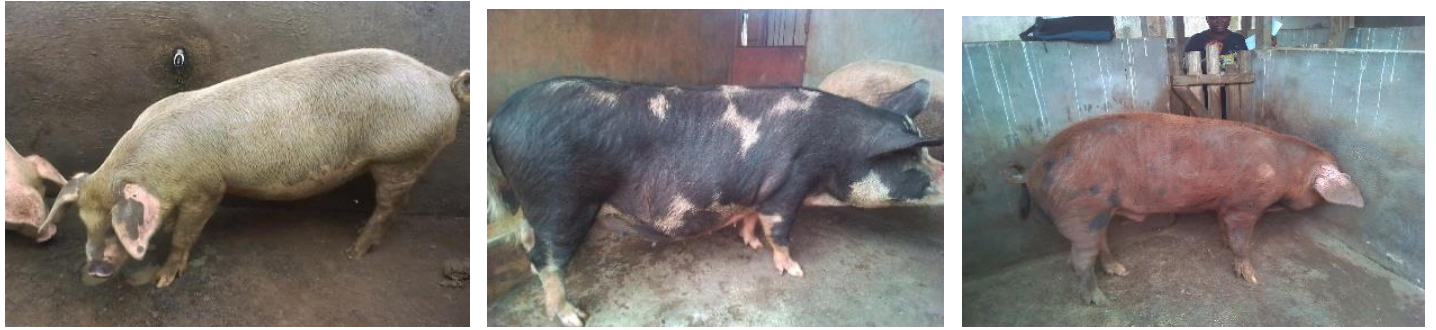

Improved piggeries with nipples, iron or wooden door

Figure 2: Various types of pig housing systems in the humid forest with monomodal rainfall agroecological zone of Cameroon. 
Table 3: Characteristics of pigs' feeding in the humid forest with monomodal rainfall agroecological zone of Cameroon.

\begin{tabular}{|c|c|c|c|c|c|}
\hline Variables & Number & Percentage & Variables & Number & Percentage \\
\hline Types of feed & & & Types of reproduction & & \\
\hline Compounded feed only & 26 & 57.8 & Free will mating & 25 & 55.6 \\
\hline $\begin{array}{l}\text { Compounded, kitchen waste } \\
\text { and grass }\end{array}$ & 7 & 15.6 & Free will and group mating & 1 & 2.2 \\
\hline $\begin{array}{l}\text { Compounded feed and kitchen } \\
\text { waste }\end{array}$ & 12 & 26.7 & Assisted mating & 4 & 8.9 \\
\hline Total & 45 & 100.0 & Group mating & 15 & 33.3 \\
\hline Feeding frequency & & & Total & 45 & 100.0 \\
\hline Once daily & 15 & 33.3 & Delivery & & \\
\hline Twice daily & 26 & 57.8 & Inside the herd & 28 & 62.20 \\
\hline Feed is always available & 4 & 8.9 & Both & 15 & 33.33 \\
\hline Total & 45 & 100.0 & Out of the herd & 2 & 4.4 \\
\hline Means of feeding & & & Total & 45 & 100.0 \\
\hline Use of feeding trough & 38 & 84.4 & Health problem & & \\
\hline Left on the floor & 7 & 15.6 & Yes & 35 & 77.8 \\
\hline Total & 45 & 100.0 & No & 10 & 22.2 \\
\hline Types of feeding trough & & & Total & 45 & 100.0 \\
\hline Concrete troughs & 13 & 28.9 & Health Prevention methods & & \\
\hline $\begin{array}{l}\text { Concrete troughs and halve } \\
\text { tyres }\end{array}$ & 1 & 2.2 & & & \\
\hline Half tyres & 6 & 13.3 & No direct entry in the farm & 6 & 13.33 \\
\hline $\begin{array}{l}\text { Concrete troughs and wooden } \\
\text { type }\end{array}$ & 1 & 2.2 & No prevention & 7 & 15.56 \\
\hline Halve tyres and plastic types & 2 & 4.4 & $\begin{array}{l}\text { Proper treatment, good } \\
\text { hygiene }\end{array}$ & 12 & 26.67 \\
\hline Wooden type & 5 & 11.1 & Vaccination & 20 & 44.44 \\
\hline Plastic types & 17 & 37.8 & & & \\
\hline Total & 45 & 100.0 & Total & 45 & 100.0 \\
\hline
\end{tabular}

Table 4: Distribution of farmers according to the marketing and profitability and challenges in pig production in the humid forest with monomodal rainfall agro-ecological zone of Cameroon.

\begin{tabular}{|c|c|c|c|c|c|}
\hline Variables & Number & Percentage & Variables & Number & Percentage \\
\hline Ready market & & & & & \\
\hline Yes & 10 & 22.22 & Challenges & & \\
\hline No & 35 & 77.78 & Bad roads and & 8 & 17.78 \\
\hline Total & 45 & 100 & disease outbreak & 15 & 33.33 \\
\hline Profitability & & & Lack of finance & 9 & 20 \\
\hline Yes & 41 & 91.11 & Feed is expensive & 10 & 22.22 \\
\hline No & 4 & 8.89 & $\begin{array}{l}\text { No support from the } \\
\text { government }\end{array}$ & 3 & 6.67 \\
\hline Total & 45 & 100 & Total & 45 & 100 \\
\hline
\end{tabular}




\section{DISCUSSION}

This study allowed to characterize pig farmers, the production system and to identify the challenges of pig production in the humid forest with monomodal rainfall agroecological zone of Cameroon. The study reveals that the proportion of pigs owners and caretakers are different from that observed in the Basse-Casamance in Senegal and in Chad (Mopate et al., 2014), showing that pig production in our study area is mostly a family business. In the traditional agricultural production, family labour plays a significant role in farm labour supply. The average farmer first exhausts all sources of labour in his family before hiring labour in order to reduce the cost of production. This could also justify the older age of the farmers and the relatively high involvement of women $(37.8 \%)$ as compare with other studies. However, men presence in this activity remain predominance. This is in agreement with the findings of Adesehinwa et al. (2003) who reported that pig production is dominated by men in Southwest Nigeria. Although this result show that pig farming is mostly carried out by males this is most likely to be due to the fact that men are capable of doing more tedious work which is usually associated with farming than the females. It does not mean that females were not highly involve in pig production in the study area. Females in this study were usually involved at different levels, from being owner to helper or suppliers of labour in light farm operation such as serving of feed, water or cleaning of the piggery. The lower participation of female farmers in raising pigs as compared to male could be as a result of drudgery, physical and energy demanding as well as capital-intensive nature of investment required by pig production, which discourages women Defang et al. (2014). However, it should be mentioned that the used of locally available materials for housing, as feedstuffs or ethno veterinary medicine has brought down the production cost, justifying the relatively high involvement of women and youth as compare with other regions of Africa.
Pig farming in the study area is $100 \%$ done by Christians. This is contrary to the findings of Adesehinwa et al. (2003) who reported $13.3 \%$ involvement of some Muslims in pig production in Oyo state, Nigeria. The high rate of the respondents in this study who education level ranging from basic to university contrasts with the $4.4 \%$ with no formal education. This agrees with Adesehinwa et al. (2003) who reported that a higher percentage of pig farmers in Oyo State of Western Nigeria had formal education. Education may be of assistance to extension officers for easy communication and understanding of extension message, especially for application of new technology in swine production and management. Literate farmers might be more likely to adopt good husbandry and health-management practices. The proportion of part-time pig farmers recorded in this study (48.90\%) disagreed with the $78.8 \%$ reported by (Ajala et al., 2007) in Kaduna State Nigeria.

According to Lekule and Kyvsgaard (2003) the traditional system of pig production in Africa i.e. "free range", "tethering" and "small scale" is more popular because it is more sustainable, less costly and, therefore, more profitable. Indeed the findings of this study show that the majority of the households in the study area were practicing housing of pigs, used compounded and homemade feeds, prefer keeping crossbreeds and relied mostly on intensive system. This is in accordance with the findings by Muhanguzi et al. (2012) where the majority of the households in central Uganda practiced intensive system and semi-intensive system. However, most of the farmer in our area of study, contrarily to Uganda, prefer keeping crossbreeds, but a good proportion (20\%) still rely on indigenous breeds, which are at $15.56 \%$ not housed. This difference could be attributable to the different socio-economic factors. According to Lekule and Kyvsgaard (2003), intensive system of pig production is feasible in areas with shortage of land and in large cities with access to industrial byproducts to feed the pigs. This is not the case in our area of study where the regional centres 
are still small with a low industrial base. Further, socio-economic indicators for the area, as shown by the higher percentage of rural people living below poverty line compared to the Cameroon average, suggest that farmers in the humid forest with monomodal rainfall agro-ecological zone of Cameroon do not have adequate financial resources to venture into more costly systems of pig production. And this could justify the high use of wood for piggery making.

The results indicate only $24.44 \%$ use of exotic breeds by farmers, mostly to improve the performances of local ones through crossbreeding (40\%), but the highly represented free will mating and the increased use of own stock and that of neighbours could give rise to inbreeding that will consequently lower performance and productivity.

Feeding is one of the most important aspects of pig farming. The feeding system reported in this study is in conformity with the results of Rahman et al. (2008) in Azawa District of Mizoram, India. Feeding kitchen waste and by- products associated with postharvest crop residues to pigs of all categories is a means of reducing feed cost with a negative impact on the pig performance.

A large proportion of farmers agreed to have health problems, but up to $15.56 \%$ declared taking no prevention methods. This result is contrasting with the findings of Rahman et al. (2008). The presence of disease outbreaks, mostly African swine fever, and feeding cost constituted the main constrains in pig production in the study area. Lack of funds in any investment constitute a set back to the establishment and growth of pig business. This situation is almost ubiquitous for all smallholder farmers in the central Africa sub-region.

\section{Conclusion}

The study was undertaken to investigate the socio-economic and technical characteristics of pig production systems. The majority of smallholder pig farmers in the humid forest with monomodal rainfall agroecological zone of Cameroon take care themselves of their herd and only a very small proportion has no formal education. All the pig rearers are Christians and have obtained their starter stock from the neighborhoods, and jointly keep local, exotic and their crossbreeds. Farmers mostly house their pigs in wooden made piggery, to avoid destruction and diseases, though the number of farmers still practicing free range production system is relatively high enough to favour spread of diseases. Most of the farmers give their animals compounded feed twice daily in feeding troughs mostly made of plastic materials and concrete. For reproduction, farmers practice mostly free will and group mating systems and delivery mostly take place inside the herd. Health problems faced are mostly due to lack of prophylactic measures, non-availability of veterinary products and insufficient technical assistance. Although pig production is recognized profitable, there is no ready market according to the large majority of farmers whose main challenges are disease outbreak and expensive feed cost.

\section{COMPETING INTERESTS}

The authors declare that they have no competing interests.

\section{AUTHORS' CONTRIBUTIONS}

JSM collected data and wrote the manuscript; CTK and HFD supervised the work.

\section{ACKNOLEDGEMENTS}

We are grateful to the farmers in the zone for their participation. We also thank the lecturers of the department of Animal Production, Faculty of Agronomy and Agricultural Sciences, University of Dschang for the scientific advices given in other to improve the quality of this work.

\section{REFERENCES}

Adesehinwa AOK, Makinde GEO, Oladele OI. 2003. Socio-economic characteristics of pig farmers as determinant of pig feeding pattern in Oyo state, 
Nigeria. Livestock Research for Rural Development, 15(12): 2003

Ajala MK, Adesehinwa AOK, Mohammed AK. 2007. Characteristics of smallholder pig production in Southern Kaduna area of Kaduna state, Nigeria. AmericanEurasian Journal of Agricultural and Environmental Sciences, 2(2): 182-188.

Ajala MK, Adesehinwa AOK, Bawa GS. 2006. Socio-Economic Characteristics Influencing Swine Management Practices Among Women in Jama'a Local Government Area of Kaduna State. Nigeria' Institute of Agricultural Research and Training, Obafemi Awolowo University: Ibadan, Nigeria; $43-48$.

Bienvenu PP, Christelle B, Andre T, Honore K, Jerome B. 2014. Smallholder pig production systems along a periurbanrural gradient in the Western provinces of the Democratic Republic of Congo. Journal of Agriculture and Rural Development in the Tropics and Subtropics, 115(1): 9-22.

Defang HF, Kana JR, Bime MJ, Ndebi G, Yemele F, Zoli PA, Manjeli Y, Teguia A, Tchoumboue J. 2014. Socioeconomic and technical characteristics of pig farming in the urban and peri - urban zone of Dschang - West region of Cameroon. Discourse Journal of Agriculture and Food Sciences, www.resjournals.org/JAFS, 2(1): 11-20

ILRI. 2000. Handbook of Livestock Statistics for Developing Countries. International Livestock Research Institute (ILRI). Working paper No. 26, Socioeconomic and Policy Research, 2000289 P.

Iyai DA, Marani O, Marjen T, Usior L. 2013. Pig farming performances of three papuan tribes: case study of Byak, Onate and Arfak Tribes in Papua Barat. J.Indonesian Trop. Anim. Agric. 38(1): 55-64.

Lekule PF Kyvsgaard CN. 2003. Improving pig husbandry in tropical resource-poor communities and its potential to reduce risk of porcine Cysticercosis. Review article. Acta Tropica, 87(1): 111-117. http://www.sciencedirect.com/science/art icle/pii/S0001706X03000263\#

Rahman S, Barthakur S, Kalita G. 2008. Pig Production and Management System in Aizawi District of Mizoram, India. Livestock Research for Rural Development, $\quad \mathbf{2 0}(9)$. DOI: http://www.lrrd.org/lrrd20/9/rahm20139. $\mathrm{htm}$ 